\title{
Significance of $\mathrm{CO}_{2}$ donor on the production of succinic acid by Actinobacillus succinogenes ATCC 55618
}

Wei Zou', Li-Wen Zhu', Hong-Mei Li ${ }^{1}$ and Ya-Jie Tang ${ }^{1,2,3,4^{*}}$

\begin{abstract}
Background: Succinic acid is a building-block chemical which could be used as the precursor of many industrial products. The dissolved $\mathrm{CO}_{2}$ concentration in the fermentation broth could strongly regulate the metabolic flux of carbon and the activity of phosphoenolpyruvate (PEP) carboxykinase, which are the important committed steps for the biosynthesis of succinic acid by Actinobacillus succinogenes. Previous reports showed that succinic acid production could be promoted by regulating the supply of $\mathrm{CO}_{2}$ donor in the fermentation broth. Therefore, the effects of dissolved $\mathrm{CO}_{2}$ concentration and $\mathrm{MgCO}_{3}$ on the fermentation process should be investigated. In this article, we studied the impacts of gaseous $\mathrm{CO}_{2}$ partial pressure, dissolved $\mathrm{CO}_{2}$ concentration, and the addition amount of $\mathrm{MgCO}_{3}$ on succinic acid production by Actinobacillus succinogenes ATCC 55618. We also demonstrated that gaseous $\mathrm{CO}_{2}$ could be removed when $\mathrm{MgCO}_{3}$ was fully supplied.

Results: An effective $\mathrm{CO}_{2}$ quantitative mathematical model was developed to calculate the dissolved $\mathrm{CO}_{2}$ concentration in the fermentation broth. The highest succinic acid production of $61.92 \mathrm{~g} / \mathrm{L}$ was obtained at 159.22 $\mathrm{mM}$ dissolved $\mathrm{CO}_{2}$ concentration, which was supplied by $40 \mathrm{~g} / \mathrm{L} \mathrm{MgCO}_{3}$ at the $\mathrm{CO}_{2}$ partial pressure of $101.33 \mathrm{kPa}$. When $\mathrm{MgCO}_{3}$ was used as the only $\mathrm{CO}_{2}$ donor, a maximal succinic acid production of $56.1 \mathrm{~g} / \mathrm{L}$ was obtained, which was just decreased by $7.03 \%$ compared with that obtained under the supply of gaseous $\mathrm{CO}_{2}$ and $\mathrm{MgCO}_{3}$.

Conclusions: Besides the high dissolved $\mathrm{CO}_{2}$ concentration, the excessive addition of $\mathrm{MgCO}_{3}$ was beneficial to promote the succinic acid synthesis. This was the first report investigating the replaceable of gaseous $\mathrm{CO} 2$ in the fermentation of succinic acid. The results obtained in this study may be useful for reducing the cost of succinic acid fermentation process.
\end{abstract}

\section{Background}

Succinic acid, an intermediate in the cycle of tricarboxylic acid (TCA), is one of four-carbon platform chemicals for producing different kinds of petroleum derivatives and biodegradable polymers $[1,2]$. Succinic acid could be produced by chemical conversion and microbial fermentation [3]. Because of the rising price, the limited reserves of petroleum and the pollution of environment, the oil-based industries had been prompted a movement towards the bio-based chemicals, and the bio-based succinic acid production had drawn the attention from enterprises and research institutes $[4,5]$.

\footnotetext{
* Correspondence: yajietang@hotmail.com

'Key Laboratory of Fermentation Engineering (Ministry of Education), Hubei University of Technology, Wuhan 430068, China

Full list of author information is available at the end of the article
}

As the end-product of the energy metabolism, succinic acid could be produced by many anaerobic microbes, such as Actinobacillus succinogenes, Anaerobiospirillum succiniciproducens, Mannheimia succiniciproducens, Escherichia coli, and other microbes $[2,4,6,7]$. Especially A. succinogenes ATCC 55618, which is a facultative anaerobe isolated from the bovine rumen [8]. In the production of succinic acid by $A$. succinogenes, one of the key factors is the supply of $\mathrm{CO}_{2}$. A higher concentration of $\mathrm{CO}_{2}$ could increase the ratio of succinic acid concentration to the other acids production, the ratio of carbon recovery, and the yield of succinic acid [9]. When A. succinogenes and A. succiniciproducens were used for the production of succinic acid, as a kind of co-substrate of phosphoenolpyruvate (PEP)-carboxykinase in the TCA cycle, $\mathrm{CO}_{2}$ could promote carbon flow toward the production of succinic

\section{Biomed Central}

(c) 2011 Zou et al; licensee BioMed Central Ltd. This is an Open Access article distributed under the terms of the Creative Commons Attribution License (http://creativecommons.org/licenses/by/2.0), which permits unrestricted use, distribution, and reproduction in any medium, provided the original work is properly cited. 
acid $[10,11]$. For the other succinic acid production microorganisms such as E. coli and Mannheimia succiniciproducens, $\mathrm{CO}_{2}$ was incorporated into the backbone of threecarbon compound to generate four-carbon oxaloacetate via PEP carboxylase to enhance the production of succinic acid $[12,13]$.

Because of the poor solubility of gaseous $\mathrm{CO}_{2}$ at 1 atm, many kinds of carbonate and bicarbonate salts were employed as indirect $\mathrm{CO}_{2}$ donor to enhance the dissolved $\mathrm{CO}_{2}$ concentration in fermentation broth. $\mathrm{MgCO}_{3}$ was a preferable carbonate because the addition of $\mathrm{MgCO}_{3}$ would not lead to a radical change of culture $\mathrm{pH}$, and an increase of $\mathrm{Mg}^{2+}$ concentration in fermentation broth showed little negative effect on the metabolism profile and morphology of succinic acid production strain [14]. Some investigators tried to demonstrate the relationship between extra $\mathrm{CO}_{2}$ donors and succinic acid production $[9,15,16]$. But there were a few different features in physiological and biochemical characteristics among various kinds of succinic acid producing strains, and the current results were weak in promoting succinic acid production $[15,16]$.

In this study, the dissolved $\mathrm{CO}_{2}$ concentration and the addition amount of $\mathrm{MgCO}_{3}$ were quantitatively determined to optimize succinic production by Actinobacillus succinogenes ATCC 55618. To calculate the dissolved $\mathrm{CO}_{2}$ concentration in the fermentation broth, a mathematical model which considers culture $\mathrm{pH}$, temperature, ionic strength, and salt concentration in the fermentation broth were developed. According to the model prediction and experimental verification, this work firstly demonstrated that the supply of gaseous $\mathrm{CO}_{2}$ had no significant effect on succinic acid production when $\mathrm{MgCO}_{3}$ was fully supplied.

\section{Methods}

Maintenance and preculture of Actinobacillus succinogenes The strain of $A$. succinogenes ATCC 55618 was purchased from American Type Culture Collection (ATCC, Manassas USA), which was maintained in $20 \%$ glycerol at $-70^{\circ} \mathrm{C}$.

The plate was inoculated with the above strain and incubated at $37^{\circ} \mathrm{C}$ for 2 days. Preculture medium consisted of the following components $(\mathrm{g} / \mathrm{L})$ : tryptone 17; soya peptone 3 ; glucose $2.5 ; \mathrm{NaCl} 5 ; \mathrm{K}_{2} \mathrm{HPO}_{4} 2.5$, and culture $\mathrm{pH}$ was adjusted to 7.1-7.5. For the first preculture, $50-\mathrm{mL}$ medium was prepared in a $250-\mathrm{mL}$ anaerobic bottle, and then a colony from a plate culture was inoculated, and followed by 12 -hour incubation at $37^{\circ} \mathrm{C}$ on a rotary shaker at $120 \mathrm{rpm}$. For the second preculture, $47.5-\mathrm{mL}$ medium was prepared in a $250-\mathrm{mL}$ anaerobic bottle, and inoculated with $2.5-\mathrm{mL}$ first preculture broth, then followed by 12 -hour incubation at $37^{\circ} \mathrm{C}$ on a rotary shaker at $120 \mathrm{rpm}$.

\section{Fermentation in the stirred-tank bioreactor}

The stirred-tank bioreactor used was a 5.0-L (working volume) BioFlo 110 New Brunswick Scientific (NJ, USA) agitated bioreactor with two six-bladed Rushton impellers (5.9-cm i.d.). The lower impeller was $2.5 \mathrm{~cm}$ above the reactor bottom, and the vertical distance between two impellers was $8.5 \mathrm{~cm}$. The reactor was aerated through a ring sparger with a pore size of $1.0 \mathrm{~mm}$, which was located $2.2 \mathrm{~cm}$ above the reactor bottom. The bioreactor was equipped with probes of $\mathrm{pH}$ (Mettler-Toledo $\mathrm{GmbH}$, Switzerland), temperature and foam.

Fermentation medium was composed of $(\mathrm{g} / \mathrm{L})$ : glucose 100; yeast extract (YE) 16; corn steep liquor (CSL) 12; $\mathrm{KH}_{2} \mathrm{PO}_{4} 3 ; \mathrm{NaCl} 1 ; \mathrm{MgCl}_{2} \cdot 6 \mathrm{H}_{2} \mathrm{O} 0.3$; and $\mathrm{CaCl}_{2} \cdot 2 \mathrm{H}_{2} \mathrm{O}$ 0.3 . Fermentation was conducted at $37^{\circ} \mathrm{C}$ and inoculated with $5 \%(\mathrm{v} / \mathrm{v})$ of the second preculture broth. The rotation speed and external $\mathrm{CO}_{2}$ gas sparging rate was $200 \mathrm{rpm}$ and $0.1 \mathrm{vvm}$. The $\mathrm{pH}$ was adjusted to 7.5 with $28 \%(\mathrm{w} / \mathrm{w})$ ammonia solutions.

Four cultures were carried out simultaneously in the stirred-tank bioreactors with homogeneous cell source under well-controlled process conditions but under different culture conditions. The identical cell source and process conditions, other than the experimental condition, made it possible to perform accurate head-to-head comparisons. The results presented here were confirmed to be reproducible in another experiment (data not shown).

\section{Model description and calculation}

When a gas mixture of $\mathrm{CO}_{2}$ and $\mathrm{N}_{2}$ was supplied into the bioreactor and became liquid-gas phase equilibrium, the $\mathrm{CO}_{2}$ dissolved concentration in broth at 1 atm could be described by the reduction of Henry's law:

$$
\mathrm{C}_{\mathrm{CO}_{2}}=\frac{P_{\mathrm{CO}_{2}}}{H}
$$

Where $P_{\mathrm{CO} 2}$ is the $\mathrm{CO}_{2}$ partial pressure $(\mathrm{kPa})$ in gas mixture which is determined by the mixing ratio of $\mathrm{CO}_{2}$ and $\mathrm{N}_{2}, \mathrm{H}$ is the Henry's constant for $\mathrm{CO}_{2}$ in the fermentation broth $(\mathrm{kPa} \cdot \mathrm{L} / \mathrm{mol})$, and $C_{\mathrm{CO} 2}$ is the dissolved $\mathrm{CO}_{2}$ concentration in the fermentation broth $(\mathrm{mol} / \mathrm{L})$.

Since a culture medium contains different kinds of salts and organic substances, the solubility of $\mathrm{CO}_{2}$ was described according to an empirical model suggested by Rischbieter et al. [17], and Weisenberger and Schumpe [18]:

$$
\log \left(\frac{H}{H_{0}}\right)=\log \left(\frac{c_{G, 0}}{c_{G}}\right)=\sum_{i}\left(h_{i}+h_{G}\right) c_{i}+\sum_{j}\left(b_{n}+b_{G}\right) c_{n, j}
$$

Where $H_{O}$ is the Henry's constant for $\mathrm{CO}_{2}$ in the pure water $(\mathrm{kPa} \cdot \mathrm{L} / \mathrm{mol}), c_{i}$ is the concentration of ion $i(\mathrm{~mol} / \mathrm{L})$, $c_{n, j}$ is the concentration of organic substance $j(\mathrm{~g} / \mathrm{L}) . c_{G}, O$ 
and $c_{G}$ denote the gas solubility in pure water and fermentation broth. $h_{i}$ indicated ion-specific parameter $(\mathrm{L} / \mathrm{mol})$, and the $h_{i}$ values are: $\mathrm{Na}^{+}: 0.1143 ; \mathrm{Ca}^{2+}: 0.1762 ; \mathrm{Mg}^{2+}$ : $0.1694 ; \mathrm{K}^{+}: 0.0922 ; \mathrm{Cl}^{-}: 0.0318 ; \mathrm{H}_{2} \mathrm{PO}_{4}^{-}: 0.0906 ; \mathrm{H}^{+}: 0 ; \mathrm{OH}^{-}$ : 0.0839; $\mathrm{HCO}_{3}{ }^{-}: 0.0976 ; \mathrm{CO}_{3}{ }^{2-}: 0.1423 . b_{n}$ indicates substance-specific model parameter $\left(\mathrm{m}^{3} / \mathrm{kg}\right)$, and the $b_{n}$ for glucose, YE and CSL are: $6.68 \times 10^{-4} \mathrm{~m}^{3} / \mathrm{kg}, 7.9 \times 10^{-4}$ $\mathrm{m}^{3} / \mathrm{kg}$, and $2.11 \times 10^{-4} \mathrm{~m}^{3} / \mathrm{kg}$. $h_{G}$ was estimated by Equation (3) following the suggestions of Weisenberger and Schumpe [18]:

$$
h_{G}=h_{G, 0}+h_{G, T}(T-298.15 K)
$$

where $h_{G, o}$ and $h_{G, T}$ for $\mathrm{CO}_{2}$ are $-0.0172 \mathrm{~L} / \mathrm{mol}$ and $-0.338 \times 10^{-3} \mathrm{~L} / \mathrm{mol} \cdot \mathrm{K}$, respectively, between $273-313 \mathrm{~K}$ [18]. And $b_{G}$ in Equation (2) was estimated by Equation (4) as suggested by Rischbieter et al. [17]:

$$
b_{\mathrm{G}}=b_{\mathrm{G}, 0}+b_{\mathrm{G}, T}(T-298.15 K)
$$

where $b_{G, o}$ and $b_{G, T}$ for $\mathrm{CO}_{2}$ are $-1.86 \times 10^{-4} \mathrm{~m}^{3} / \mathrm{kg}$ and $0.01 \times 10^{-4} \mathrm{~m}^{3} / \mathrm{kg} \cdot \mathrm{K}$, respectively, between $283-303 \mathrm{~K}$ [17]. Combining Equations (2), (3) and (4), a model of Henry's constant for $\mathrm{CO}_{2}$ in fermentation medium could be obtained.

$$
\log \left(\frac{H}{H_{0}}\right)=\sum_{i}\left(h_{i}+h_{G, 0}+h_{G, T}(T-298.15 K)\right) c_{i}+\sum_{j}\left(b_{n}+b_{G, 0}+b_{G, T}(T-298.15 K)\right) c_{n, j}
$$

In Equation (5), the Henry's constant of $\mathrm{CO}_{2}$ in the pure water was $4320 \mathrm{kPa} \mathrm{L} / \mathrm{mol} \mathrm{[15].} T$ is the absolute temperature $(\mathrm{K})$ in culture condition.

After combining all the parameters mentioned above into the Equation (5) and Equation (1), the model used for calculating $\mathrm{CO}_{2}$ dissolved concentration in broth could be obtained when gaseous $\mathrm{CO}_{2}$ was used as external $\mathrm{CO}_{2}$ donor and the result is shown in Figure 1A. There is a correlated linear trend between $\mathrm{CO}_{2}$ partial pressure and the dissolved $\mathrm{CO}_{2}$ concentration in fermentation broth. The dissolved $\mathrm{CO}_{2}$ concentration in the fermentation broth was 5.05, 10.11, 15.16 and 20.22 $\mathrm{mM}$ when $\mathrm{CO}_{2}$ partial pressure was $25.33,50.66,75.99$ and $101.33 \mathrm{kPa}$, respectively. And the maximal dissolved $\mathrm{CO}_{2}$ concentration is $20.22 \mathrm{mM}$ due to the solubility of gaseous $\mathrm{CO}_{2}$.

When $\mathrm{MgCO}_{3}$ was added with the supply of pure gaseous $\mathrm{CO}_{2}$ at 1 atm, $\mathrm{CO}_{2}, \mathrm{HCO}_{3}^{-}$, and $\mathrm{CO}_{3}{ }^{2-}$ would become in equilibrium in the fermentation broth according to the following equations [15]:

$$
\begin{aligned}
& \mathrm{CO}_{2}+\mathrm{H}_{2} \mathrm{O} \leftrightarrow \mathrm{HCO}_{3}^{-}+\mathrm{H}^{+} \\
& \mathrm{HCO}_{3}^{-} \leftrightarrow \mathrm{CO}_{3}^{2-}+\mathrm{H}^{+}
\end{aligned}
$$

As reported in the previous study [19], the maximum solubility of $\mathrm{MgCO}_{3}$ in water at $40^{\circ} \mathrm{C}$ was $139 \mathrm{mM}$.
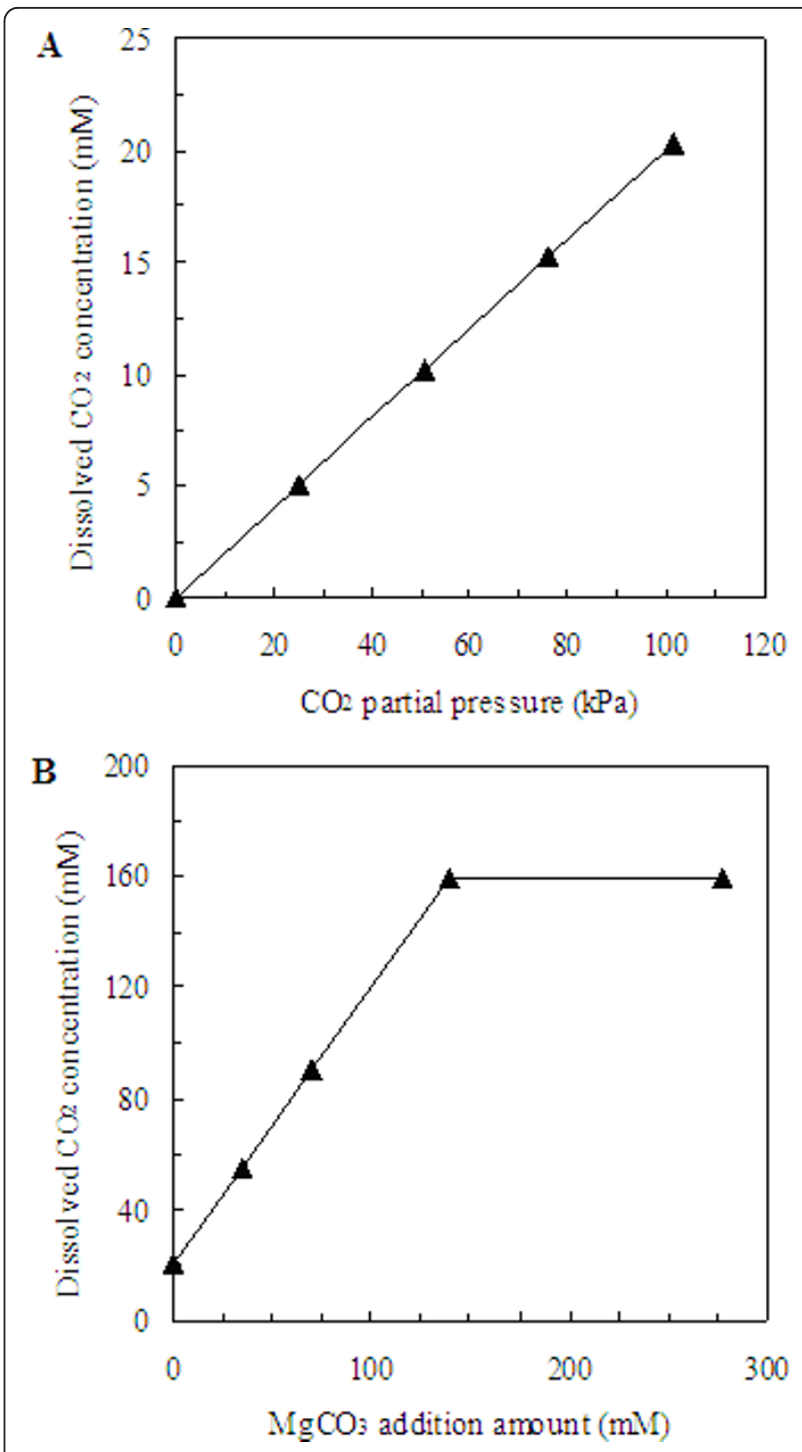

Figure 1 Effects of gaseous $\mathrm{CO}_{2}$ and $\mathrm{MgCO}_{3}$ on the dissolved $\mathrm{CO}_{2}$ concentration in the fermentation broth. (A): The dissolved $\mathrm{CO}_{2}$ concentration in the fermentation broth with the sole supply of various $\mathrm{CO}_{2}$ partial pressures. (B): The dissolved $\mathrm{CO}_{2}$

concentration in the fermentation broth with the addition of various amount of $\mathrm{MgCO}_{3}$ at the $\mathrm{CO}_{2}$ partial pressure of $101.33 \mathrm{kPa}$ (i.e., $100 \% \mathrm{CO}_{2}$ gas).

According to Equation (1), (5), (6) and (7), the model used for calculating the dissolved $\mathrm{CO}_{2}$ concentration in the fermentation broth could be obtained when both gas phase $\mathrm{CO}_{2}$ and $\mathrm{MgCO}_{3}$ were used as $\mathrm{CO}_{2}$ donors, and the relationship between the addition amount of $\mathrm{MgCO}_{3}$ and the dissolved $\mathrm{CO}_{2}$ concentration under the $\mathrm{CO}_{2}$ partial pressure of $101.33 \mathrm{kPa}$ is shown in Figure 1B. The $\mathrm{CO}_{2}$ concentrations in the fermentation broth were $20.22,54.97,89.72,159.22$ and $159.22 \mathrm{mM}$ when the addition of $\mathrm{MgCO}_{3}$ was $0,2.92,5.84,11.68$, and $23.35 \mathrm{~g} / \mathrm{L}$, respectively. And the maximum dissolved 
$\mathrm{CO}_{2}$ concentration is $159.22 \mathrm{mM}$ due to the solubility of gaseous $\mathrm{CO}_{2}$ and $\mathrm{MgCO}_{3}$.

\section{Effect of $\mathrm{CO}_{2}$ partial pressure}

The significance of gaseous $\mathrm{CO}_{2}$ partial pressure on succinic acid accumulation was studied by setting $\mathrm{CO}_{2}$ partial pressure at 25.33, 50.66, 75.99 and $101.33 \mathrm{kPa}$ during the whole fermentation process in the stirredtank bioreactors, which was controlled by adjusting the corresponding mixing ratio of $\mathrm{CO}_{2}$ and $\mathrm{N}_{2}$ at $25 \%, 50 \%$, $75 \%, 100 \%$ (v: v) by gas mix controller (BioFlo110, New Brunswick Scientic NJ, USA), respectively, and the corresponding dissolved $\mathrm{CO}_{2}$ concentration in the fermentation broth was 5.05, 10.11, 15.16, and $20.22 \mathrm{mM}$.

\section{Effect of the supply of gaseous $\mathrm{CO}_{2}$ and the addition of $\mathrm{MgCO}_{3}$}

The maximal dissolved $\mathrm{CO}_{2}$ concentration in the fermentation broth was 20.22 and $139.00 \mathrm{mM}$ when only gaseous $\mathrm{CO}_{2}$ and $\mathrm{MgCO}_{3}$ was supplied, respectively. In order to study the higher dissolved $\mathrm{CO}_{2}$ concentration on the succinic acid production, the fermentations were conducted by adding $\mathrm{MgCO}_{3}$ to enhance the dissolved $\mathrm{CO}_{2}$ concentration. $\mathrm{MgCO}_{3}$ was added to the broth after a separate sterilization before the inoculation. The effect of the supply of gaseous $\mathrm{CO}_{2}$ and the addition of $\mathrm{MgCO}_{3}$ on the fermentation process was studied by adding 2.92 , $5.84,11.68$, and $23.35 \mathrm{~g} / \mathrm{L}$ of $\mathrm{MgCO}_{3}$ at the $\mathrm{CO}_{2}$ partial pressure of $101.33 \mathrm{kPa}$ (i.e., $100 \% \mathrm{CO}_{2}$ gas), and its corresponding dissolved $\mathrm{CO}_{2}$ concentrations in the fermentation broth were 54.97, 89.72, 159.22 and $159.22 \mathrm{mM}$, respectively. The dissolved $\mathrm{CO}_{2}$ concentration maintained constant at $159.22 \mathrm{mM}$ even when concentrations higher than $11.68 \mathrm{~g} / \mathrm{L}$ of $\mathrm{MgCO}_{3}$ were added at the $\mathrm{CO}_{2}$ partial pressure of $101.33 \mathrm{kPa}$. The other culture conditions were the same as the above experiments.

\section{Effect of the addition of higher amount of $\mathrm{MgCO}_{3}$}

Effect of the excessive addition amount of $\mathrm{MgCO}_{3}$ was studied by adding 30, 40, 50 and $60 \mathrm{~g} / \mathrm{L}$ of $\mathrm{MgCO}_{3}$ at the $\mathrm{CO}_{2}$ partial pressure of $101.33 \mathrm{kPa}$ (i.e., $100 \% \mathrm{CO}_{2}$ gas), and all the corresponding dissolved $\mathrm{CO}_{2}$ concentration in the fermentation broth was $159.22 \mathrm{mM}$. The other culture conditions were the same as the above experiments.

\section{Effect of $\mathrm{CO}_{2}$ donor supply mode}

According to the above results and Equation (5), the effect of $\mathrm{CO}_{2}$ donor supply mode was studied by using two supply modes: $40 \mathrm{~g} / \mathrm{L} \mathrm{MgCO}_{3}$ was used as the only $\mathrm{CO}_{2}$ donor, and $40 \mathrm{~g} / \mathrm{L} \mathrm{MgCO}_{3}$ was supplied at the $\mathrm{CO}_{2}$ partial pressure of $101.33 \mathrm{kPa}$ (i.e., $100 \% \mathrm{CO}_{2}$ gas). The other culture conditions were the same as the above experiments.
Sampling, the determination of succinic acid production For sampling, about 20-30 mL of broth was taken once from each reactor and the cell growth was monitored by measuring the optical density at $660 \mathrm{~nm}\left(\mathrm{OD}_{660}\right)$. At an $\mathrm{OD}_{660}$ of 1.0, A. succinogenes ATCC 55618 has a concentration of $0.626 \mathrm{~g}$ dry cell weight (DCW)/L. For succinic acid determination, $1 \mathrm{~mL}$ methanol and $1 \mathrm{~mL}$ acetonitrile were added to $1 \mathrm{~mL}$ fermentation broth to remove protein and the sample was kept at $4^{\circ} \mathrm{C}$ overnight. After centrifuging at $11,000 \mathrm{rpm}$ for $30 \mathrm{~min}$, the supernatants were diluted and filtrated through $0.22 \mu \mathrm{m}$ filter, then analyzed by high-performance liquid chromatography (HPLC, Dionex) using Maisch ReproSil-Pur Basic C18

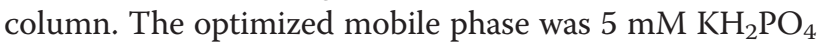
water solution, whose $\mathrm{pH}$ was adjusted to 2.8 by $\mathrm{H}_{3} \mathrm{PO}_{4}$. The column oven temperature was maintained at $40^{\circ} \mathrm{C}$ and the flow rate was $1 \mathrm{~mL} / \mathrm{min}$. The detection wave was $210 \mathrm{~nm}$. Residual sugar level was assayed with phenolsulfuric acid method [20].

\section{Results and discussion}

\section{Effect of $\mathrm{CO}_{2}$ partial pressure}

As one of the direct substrates for the biosynthesis of succinic acid, $\mathrm{CO}_{2}$ could affect the metabolic flux and the mass distribution of succinic acid [8,21]. The quantitative determination of the dissolved $\mathrm{CO}_{2}$ concentration in the fermentation broth is beneficial to study the impact of $\mathrm{CO}_{2}$ partial pressure on the production of succinic acid. Song et al. [15] and Lee et al. [16] reported that succinic acid production could be enhanced by increasing $\mathrm{CO}_{2}$ partial pressure in the fermentation of M. succiniciproducens and A. succiniciproducens. Therefore, it was necessary to investigate the effect of $\mathrm{CO}_{2}$ partial pressure on the accumulation of succinic acid by $A$. succinogenes ATCC 55618.

The effect of $\mathrm{CO}_{2}$ partial pressure on the succinic acid production is shown in Figure 2A. When the $\mathrm{CO}_{2}$ partial pressures were 25.33, 50.66, 75.99, and $101.33 \mathrm{kPa}$, the dissolved $\mathrm{CO}_{2}$ concentrations in the fermentation broth calculated using Equation (5) was 5.05, 10.11, 15.16 , and $20.22 \mathrm{mM}$, respectively (Table 1 ). And at the $\mathrm{CO}_{2}$ partial pressure of $101.33 \mathrm{kPa}$, the maximal dissolved $\mathrm{CO}_{2}$ concentration achieved was $20.22 \mathrm{mM}$, which was the highest dissolved $\mathrm{CO}_{2}$ concentration when only gaseous $\mathrm{CO}_{2}$ was supplied. The dissolved $\mathrm{CO}_{2}$ concentration was increased with the increase of the partial pressure when gaseous $\mathrm{CO}_{2}$ was used as sole $\mathrm{CO}_{2}$ donor. The succinic acid productions were 8.84, $10.21,10.44$, and $10.97 \mathrm{~g} / \mathrm{L}$ as obtained on 48 hour at the $\mathrm{CO}_{2}$ partial pressure of $25.33,50.66,75.99$, and $101.33 \mathrm{kPa}$, respectively, and its corresponding productivities were $0.18,0.21,0.22$, and $0.23 \mathrm{~g} / \mathrm{L}$ per hour. This indicated that when gaseous $\mathrm{CO}_{2}$ was used as the sole $\mathrm{CO}_{2}$ donor, $\mathrm{CO}_{2}$ partial pressure showed no significant 

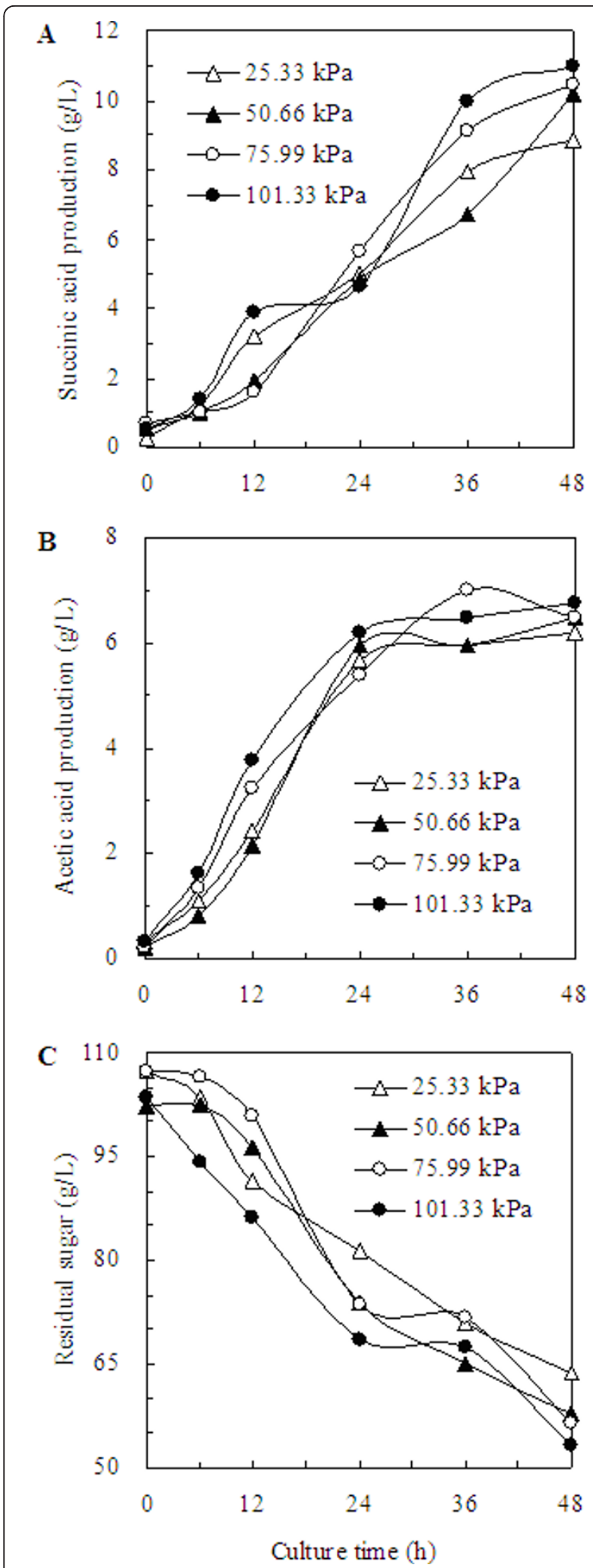

Figure 2 Effect of $\mathrm{CO}_{2}$ partial pressure on the succinic acid production during the $A$. succinogenes fermentation. (A) the succinic acid production, (B) the acetic acid production, (C) the sugar consumption. effect on the succinic acid accumulation. On the contrary, as reported by Lu et al. [22] and Samuelov et al. [23], a higher available $\mathrm{CO}_{2}$ concentration could cause higher succinic acid production by increasing the activity of PEP carboxykinase. These indicated that when gaseous $\mathrm{CO}_{2}$ was used as the sole $\mathrm{CO}_{2}$ donor, the available dissolved $\mathrm{CO}_{2}$ concentration was not high enough to increase the production of succinic acid in the fermentation of A. succinogenes.

As shown in Figure 2B, the patterns of acetic acid production at various $\mathrm{CO}_{2}$ partial pressures were similar. The concentrations of other by-products such as formic acid, lactic acid and ethanol were relatively constant at around 5.0, 11.0 and $2.0 \mathrm{~g} / \mathrm{L}$, respectively, regardless of the levels of the dissolved $\mathrm{CO}_{2}$ in the broth.

Figure $2 \mathrm{C}$ shows the time profile of residual sugar under various $\mathrm{CO}_{2}$ partial pressures. The glucose concentration at the $\mathrm{CO}_{2}$ partial pressure of $101.33 \mathrm{kPa}$ was decreased faster than that at other $\mathrm{CO}_{2}$ partial pressures during the first 24 hours. The yield of succinic acid against glucose was around $0.21 \mathrm{~g}$ succinic acid/g glucose when gaseous $\mathrm{CO}_{2}$ was used. That means the $\mathrm{CO}_{2}$ partial pressure showed no significant effect on the succinic acid yield. And there was no significant effect on the cell growth. The $\mathrm{OD}_{660}$ was between 6.0 and 6.7 when gaseous $\mathrm{CO}_{2}$ partial pressure was 25.33, 50.66, 75.99, and $101.33 \mathrm{kPa}$ (Table 1).

\section{Effect of the supply of gaseous $\mathrm{CO}_{2}$ and the addition of $\mathrm{MgCO}_{3}$}

The maximal dissolved $\mathrm{CO}_{2}$ concentration is limited by the solubility of gaseous $\mathrm{CO}_{2}$ when it was supplied as the sole $\mathrm{CO}_{2}$ donor. In order to investigate the effect of higher dissolved $\mathrm{CO}_{2}$ concentration on succinic acid production, the fermentations were conducted by adding $\mathrm{MgCO}_{3}$ at the $\mathrm{CO}_{2}$ partial pressure of $101.33 \mathrm{kPa}$ (i.e., $100 \% \mathrm{CO}_{2}$ gas) to enhance the dissolved $\mathrm{CO}_{2}$ concentration in the fermentation broth.

The effect of the supply of gaseous $\mathrm{CO}_{2}$ and the addition of $\mathrm{MgCO}_{3}$ on the fermentation process was studied by adding 2.92, 5.84, 11.68, and $23.35 \mathrm{~g} / \mathrm{L}$ of $\mathrm{MgCO}_{3}$ at the $\mathrm{CO}_{2}$ partial pressure of $101.33 \mathrm{kPa}$ (i.e., $100 \% \mathrm{CO}_{2}$ gas), and the corresponding dissolved $\mathrm{CO}_{2}$ concentrations was 54.97, 89.72, 159.22, and $159.22 \mathrm{mM}$. Because of the solubility of $\mathrm{MgCO}_{3}$ and $\mathrm{CO}_{2}$, the maximal dissolved $\mathrm{CO}_{2}$ concentration of $159.22 \mathrm{mM}$ was obtained under the addition of $11.68 \mathrm{~g} / \mathrm{L} \mathrm{MgCO}_{3}$ with $100 \% \mathrm{CO}_{2}$ gas. Even more than $11.68 \mathrm{~g} / \mathrm{L}$ of $\mathrm{MgCO}_{3}$, the dissolved $\mathrm{CO}_{2}$ concentration maintained constant at $159.22 \mathrm{mM}$. As shown in Figure 3A, the highest succinic acid productions were $15.26,15.94,25.86$ and $36.84 \mathrm{~g} / \mathrm{L}$ as obtained on 48 hour with the addition of 2.92, 5.84, 11.68 and $23.35 \mathrm{~g} / \mathrm{L} \mathrm{MgCO}_{3}$, respectively, and its corresponding productivity was $0.32,0.33,0.54$ and $0.77 \mathrm{~g} / \mathrm{L}$ per hour, 
Table 1 Effect of $\mathrm{CO}_{2}$ donor on the growth of A.succinogenes and succinic acid production parameters

\begin{tabular}{|c|c|c|c|c|c|c|}
\hline $\begin{array}{c}\text { Addition amount } \\
\text { of } \mathrm{MgCO}_{3} \\
(\mathrm{~g} / \mathrm{L})\end{array}$ & $\begin{array}{l}\text { Gaseous } \mathrm{CO}_{2} \text { partial } \\
\text { pressure }(\mathrm{kPa})^{\mathrm{a}}\end{array}$ & $\begin{array}{l}\text { Dissolved } \mathrm{CO}_{2} \\
\text { concentration }(\mathrm{mM})\end{array}$ & $O D_{660}$ & $\begin{array}{l}\text { Succinic acid productivity } \\
\text { (g/L per hour) }\end{array}$ & $\begin{array}{l}\text { Specific succinic acid productivity (g } \\
\text { succinic acid/g DCW) }\end{array}$ & $\begin{array}{l}\text { Yield of succinic acid against glucose (g } \\
\text { succinic acid/g glucose) }\end{array}$ \\
\hline$a^{a}$ & 25.33 & 5.05 & 6.61 & 0.18 & 3.50 & 0.19 \\
\hline- & 50.66 & 10.11 & 6.69 & 0.21 & 3.23 & 0.22 \\
\hline - & 75.99 & 15.16 & 6.51 & 0.22 & 3.10 & 0.19 \\
\hline- & 101.33 & 20.22 & 6.03 & 0.23 & 3.57 & 0.21 \\
\hline 2.92 & 101.33 & 54.97 & 10.12 & 0.32 & 2.71 & 0.27 \\
\hline 5.84 & 101.33 & 89.72 & 10.27 & 0.33 & 2.93 & 0.26 \\
\hline 11.68 & 101.33 & 159.22 & 9.72 & 0.54 & 5.13 & 0.38 \\
\hline 23.35 & 101.33 & 159.22 & 10.94 & 0.77 & 6.53 & 0.45 \\
\hline 30 & 101.33 & 159.22 & 9.10 & 0.74 & 11.04 & 0.56 \\
\hline 40 & 101.33 & 159.22 & 9.62 & 0.86 & 13.60 & 0.60 \\
\hline 50 & 101.33 & 159.22 & 9.74 & 0.85 & 12.66 & 0.64 \\
\hline 60 & 101.33 & 159.22 & 9.62 & 0.81 & 11.44 & 0.63 \\
\hline 40 & 101.33 & 159.22 & 10.31 & 0.84 & 12.02 & 0.58 \\
\hline 40 & - & 139.00 & 9.65 & 0.80 & 11.77 & 0.54 \\
\hline
\end{tabular}

Gas mixture was composed of $\mathrm{CO}_{2}$ and $\mathrm{N}_{2}$.

$b$ - means the $\mathrm{CO}_{2}$ donor was not add. 

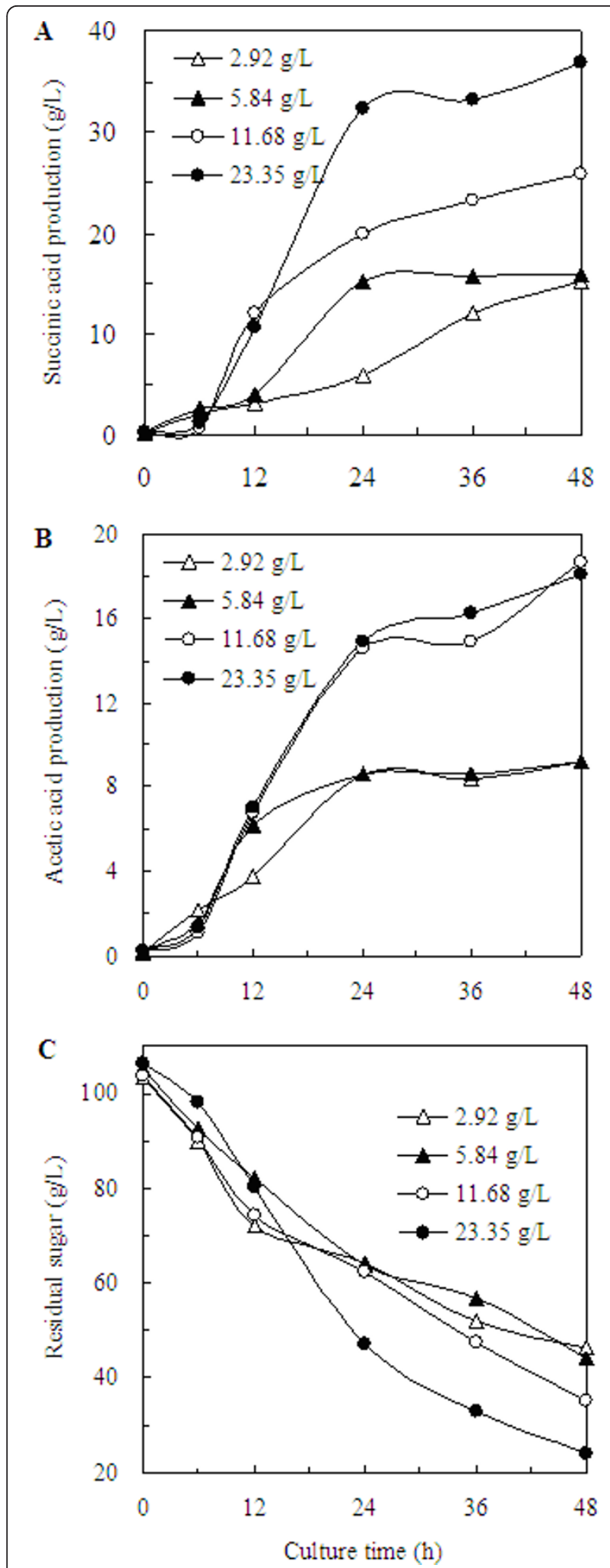

Figure 3 Effect of the supply of gaseous $\mathrm{CO}_{2}$ and the addition of $\mathbf{M g C O}_{3}$. (A) the succinic acid production, (B) the acetic acid production, (C) the sugar consumption. The fermentation was performed at the $\mathrm{CO}_{2}$ partial pressure of $101.33 \mathrm{kPa}$. respectively. The maximum succinic acid production was increased from 25.86 to $36.84 \mathrm{~g} / \mathrm{L}$ when the addition amount of $\mathrm{MgCO}_{3}$ was increased from 11.68 to 23.35 $\mathrm{g} / \mathrm{L}$, while the dissolved $\mathrm{CO}_{2}$ concentration was maintained constant. It can be concluded that the higher dissolved $\mathrm{CO}_{2}$ concentration was beneficial for the succinic acid biosynthesis. But the dissolved $\mathrm{CO}_{2}$ concentration was not the only factor affecting succinic acid synthesis; the excessive $\mathrm{MgCO}_{3}$ also had positive effect. As a kind of neutralization reagent, $\mathrm{MgCO}_{3}$ could promptly neutralize the organic acid produced during the fermentation process. But when only $11.68 \mathrm{~g} / \mathrm{L}$ of $\mathrm{MgCO}_{3}$ was added, the saturated state of $\mathrm{MgCO}_{3}$ would be lost quickly because of the rapid accumulation of organic acid during the fermentation. And when the addition amounts of $\mathrm{MgCO}_{3}$ exceeded $11.68 \mathrm{~g} / \mathrm{L}$, there will be excessive solid $\mathrm{MgCO}_{3}$ precipitate. Even if organic acids accumulate, $\mathrm{MgCO}_{3}$ solution can also keep saturated.

Equation (6) and (7) indicated that the dissolved concentrations of $\mathrm{HCO}_{3}{ }^{-}, \mathrm{CO}_{3}{ }^{2-}$ and $\mathrm{CO}_{2}$ could be enhanced with the addition of $\mathrm{MgCO}_{3}$ in the fermentation broth. However, $\mathrm{MgCO}_{3}$ may not be used as $\mathrm{CO}_{3}{ }^{2-}$ donor because there were few reports that $\mathrm{CO}_{3}{ }^{2-}$ could be used directly as substrate by succinic acid producing microorganisms. Although $\mathrm{HCO}_{3}{ }^{-}$and $\mathrm{CO}_{2}$ could be used as the co-substrate of PEP carboxylase and improve the production of succinic acid [23], $\mathrm{HCO}_{3}{ }^{-}$ was much less permeable to lipid cell membrane than the uncharged $\mathrm{CO}_{2}$ molecule because is a kind of polar molecular, and there was no $\mathrm{HCO}_{3}{ }^{-}$transporter on the membrane of $A$. succinogenes which could deliver $\mathrm{HCO}_{3}{ }^{-}$from the broth into the cell [24]. So the higher concentration of $\mathrm{HCO}_{3}{ }^{-}$could not promote the production of succinic acid. And $\mathrm{MgCO}_{3}$ may be used as indirect $\mathrm{CO}_{2}$ molecule donor to promote the production of succinic acid in the fermentation process of A. succinogenes. On the other hand, when the levels of dissolved $\mathrm{CO}_{2}$ reached $159.22 \mathrm{mM}$, there would be insoluble $\mathrm{MgCO}_{3}$, and that could cause turbid broth. The cells were spread uniformly in the broth, which was helpful to eliminate the cell flocculation and indirectly promoting the succinic acid biosynthesis.

As shown in Figure 3B, the patterns of acetic acid production at the dissolved $\mathrm{CO}_{2}$ concentration of 54.97 and $89.72 \mathrm{mM}$ were similar. However, when the levels of dissolved $\mathrm{CO}_{2}$ reached $159.22 \mathrm{mM}$, the acetic acid production was significantly enhanced. It was distinct from other reports. In the fermentation of M. succiniciproducens, the levels of dissolved $\mathrm{CO}_{2}$ showed little effects on the acetic acid accumulation [15]. The $\mathrm{CO}_{2}$ concentration has been shown to regulate the levels PEP carboxykinase pathway at high $\mathrm{CO}_{2}$ levels, and PEP carboxykinase levels rise [23]. However, the enhanced PEP carboxylation may cause higher glucose consumption rate. This effect may cause 
more metabolic flow by PEP to pyruvic acid, and further to acetic acid. Meanwhile the production of formic acid, lactic acid and ethanol almost not be improved may be because the raised PEP carboxykinase activity competitively inhibited these key enzymes such as pyruvate formatelyase, lactate dehydrogenase and ethanol dehydrogenase.

The patterns of cell growth with the addition of different concentration of $\mathrm{MgCO}_{3}$ were similar, and the $\mathrm{OD}_{660}$ was between 9.7 and 10.9 (Table 1). Figure 3C shows the time profile of residual sugar under various addition amount of $\mathrm{MgCO}_{3}$. When $23.35 \mathrm{~g} / \mathrm{L}$ of $\mathrm{MgCO}_{3}$ was added, glucose was consumed faster than the other conditions between 12 and 24 hour, which corresponded well to the succinic acid accumulation. The yield of succinic acid against glucose was $0.27,0.26,0.38$, and $0.45 \mathrm{~g}$ succinic acid/g glucose when the addition amount of $\mathrm{MgCO}_{3}$ was 2.92, 5.84, 11.68 and $23.35 \mathrm{~g} / \mathrm{L}$, respectively. This indicated that the higher dissolved $\mathrm{CO}_{2}$ concentration could effectively improve the yield of succinic acid against glucose.

\section{Effect of the addition of higher amount of $\mathrm{MgCO}_{3}$}

Effect of the higher addition amount of $\mathrm{MgCO}_{3}$ was studied by adding 30, 40, 50 and $60 \mathrm{~g} / \mathrm{L}$ of $\mathrm{MgCO}_{3}$ at the $\mathrm{CO}_{2}$ partial pressure of $101.33 \mathrm{kPa}$ (i.e., $100 \% \mathrm{CO}_{2}$ gas), and all the corresponding dissolved $\mathrm{CO}_{2}$ concentration in the fermentation broth were $159.22 \mathrm{mM}$.

As shown in Figure 4A, the pattern of succinic acid production under various addition amount of $\mathrm{MgCO}_{3}$ within the range of investigation was similar. The maximal succinic acid production of $53.55,61.92,61.48$, and $58.05 \mathrm{~g} / \mathrm{L}$ was obtained with the addition of $30,40,50$, and $60 \mathrm{~g} / \mathrm{L} \mathrm{MgCO}_{3}$, respectively, and its corresponding productivity was $0.74,0.86,0.85$ and $0.81 \mathrm{~g} / \mathrm{L}$ per hour. When the addition amount of $\mathrm{MgCO}_{3}$ exceeded $40 \mathrm{~g} / \mathrm{L}$, the production and productivity of succinic acid were kept almost constant, but the specific productivity was decreased. This indicated $40 \mathrm{~g} / \mathrm{L} \mathrm{MgCO}_{3}$ was enough for improving the accumulation of succinic acid. Similarly, Du et al. [25] reported when the addition amount of $\mathrm{MgCO}_{3}$ exceeded $30 \mathrm{~g} / \mathrm{L}$, there was no significant change on the production of succinic acid.

The significance of addition amount of $\mathrm{MgCO}_{3}$ on acetic acid accumulation was studied. As shown in Figure $4 \mathrm{~B}$, there was no significant effect on the biosynthesis of acetic acid. Similarly, the concentrations of other by-products such as formic acid, lactic acid and ethanol were relatively constant at around 5.0, 11.0 and $2.0 \mathrm{~g} / \mathrm{L}$, respectively, regardless of the addition amount of $\mathrm{MgCO}_{3}$.

The cell growth patterns under the addition of $\mathrm{MgCO}_{3}$ were quite similar (Table 1 ). Figure $4 \mathrm{C}$ shows that the time profile of residual sugar under various addition amount of $\mathrm{MgCO}_{3}$. The yield of succinic acid against glucose was $0.56,0.60,0.64$, and $0.63 \mathrm{~g}$ succinic acid/g glucose when the addition amount of $\mathrm{MgCO}_{3}$
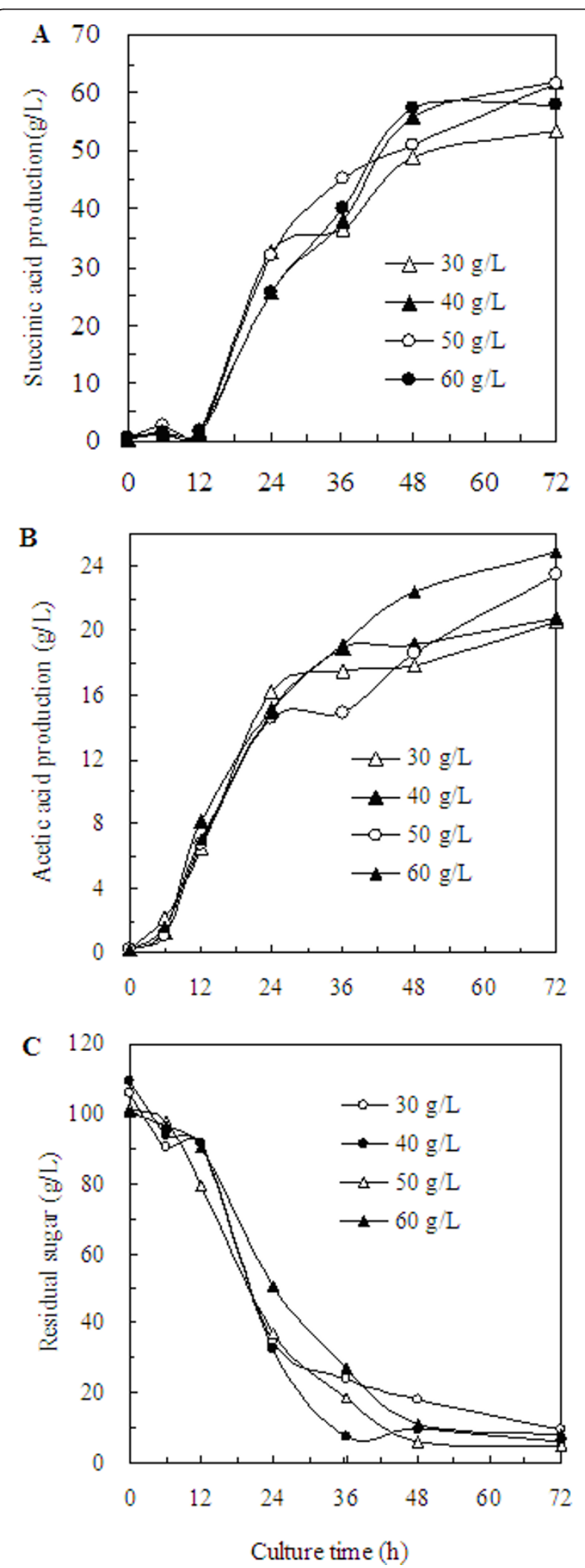

Figure 4 Effect of the excessive addition amount of $\mathrm{MgCO}_{3}$ on the succinic acid production. (A) the succinic acid production, (B) the acetic acid production, (C) the sugar consumption. 
was $30,40,50$ and $60 \mathrm{~g} / \mathrm{L}$, respectively. It seemed that to obtain a higher yield of succinic acid against glucose, the addition amount of $\mathrm{MgCO}_{3}$ should no be more than $50 \mathrm{~g} / \mathrm{L}$.

\section{Effect of $\mathrm{CO}_{2}$ donor supply mode}

Gaseous $\mathrm{CO}_{2}$ was widely used as external $\mathrm{CO}_{2}$ donor and anaerobic environment maintenance agent in succinic acid fermentation process. Calculated from Equation $(5,6,7)$, the dissolved $\mathrm{CO}_{2}$ concentration $(139.00 \mathrm{mM})$ under $40 \mathrm{~g} /$ $\mathrm{L} \mathrm{MgCO}_{3}$ was just decreased by $12.76 \%$ comparing with that obtained under the addition of $40 \mathrm{~g} / \mathrm{L} \mathrm{MgCO}_{3}$ with $100 \% \mathrm{CO}_{2}$ gas. This suggested that the gaseous $\mathrm{CO}_{2}$ may be removed by the addition of $\mathrm{MgCO}_{3}$. In order to testify this proposal, the effect of $\mathrm{CO}_{2}$ donor supply mode was studied by using two supply modes: $40 \mathrm{~g} / \mathrm{L}^{\mathrm{MgCO}_{3}}$ was used alone; $40 \mathrm{~g} / \mathrm{L} \mathrm{MgCO}_{3}$ was supplied with $100 \% \mathrm{CO}_{2}$ gas.

As shown in Figure 5A, after $72 \mathrm{~h}$ incubation, the production of succinic acid reached 56.14 and $60.38 \mathrm{~g} / \mathrm{L}$ when $40 \mathrm{~g} / \mathrm{L} \mathrm{MgCO}_{3}$ was used as the only $\mathrm{CO}_{2}$ donor and $40 \mathrm{~g} / \mathrm{L} \mathrm{MgCO}_{3}$ was supplied at the $\mathrm{CO}_{2}$ partial pressure of $101.33 \mathrm{kPa}$, and the corresponding productivity was 0.80 and $0.84 \mathrm{~g} / \mathrm{L}$ per hour. The succinic acid production was just decreased by $7.03 \%$ without the supply of gaseous $\mathrm{CO}_{2}$. As shown in Figure 5B, the acetic acid production was decreased by $17.91 \%$ without the supply of gaseous $\mathrm{CO}_{2}$. Figure $5 \mathrm{C}$ clearly shows the time courses of sugar consumption under different $\mathrm{CO}_{2}$ supply modes were similar. The yield of succinic acid against glucose was $0.54 \mathrm{~g}$ succinic acid/g glucose when $40 \mathrm{~g} / \mathrm{L} \mathrm{MgCO}_{3}$ was used alone, and the yield was $0.58 \mathrm{~g}$ succinic acid/g glucose when $\mathrm{MgCO}_{3}$ was supplied with $100 \% \mathrm{CO}_{2}$. And there was no significant effect on the cell growth whether gaseous $\mathrm{CO}_{2}$ was used.

\section{Conclusions}

In this study, an effective $\mathrm{CO}_{2}$ quantitative mathematical model was developed to calculate the dissolved $\mathrm{CO}_{2}$ concentration in the broth during the fermentation of Actinobacillus succinogenes ATCC 55618. The model offered a quantitative method for screening the suitable $\mathrm{CO}_{2}$ donor form and addition amount for the production of succinic acid. There was no significant effect of $\mathrm{CO}_{2}$ partial pressure on the production of succinic acid when gaseous $\mathrm{CO}_{2}$ was used as the sole $\mathrm{CO}_{2}$ donor. But when gaseous $\mathrm{CO}_{2}$ was used with $\mathrm{MgCO}_{3}$, higher amount of $\mathrm{MgCO}_{3}$ was more effective on promoting the succinic acid synthesis. And the maximum succinic acid production of $61.92 \mathrm{~g} / \mathrm{L}$ was obtained at $159.22 \mathrm{mM}$ dissolved $\mathrm{CO}_{2}$ concentration, which was supplied by $40 \mathrm{~g} / \mathrm{L}$ $\mathrm{MgCO}_{3}$ with $100 \% \mathrm{CO}_{2}$ gas. And it was concluded that the supply of gaseous $\mathrm{CO} 2$ was not essential when $40 \mathrm{~g} /$ $\mathrm{L}$ of $\mathrm{MgCO}_{3}$ was added in the fermentation medium.
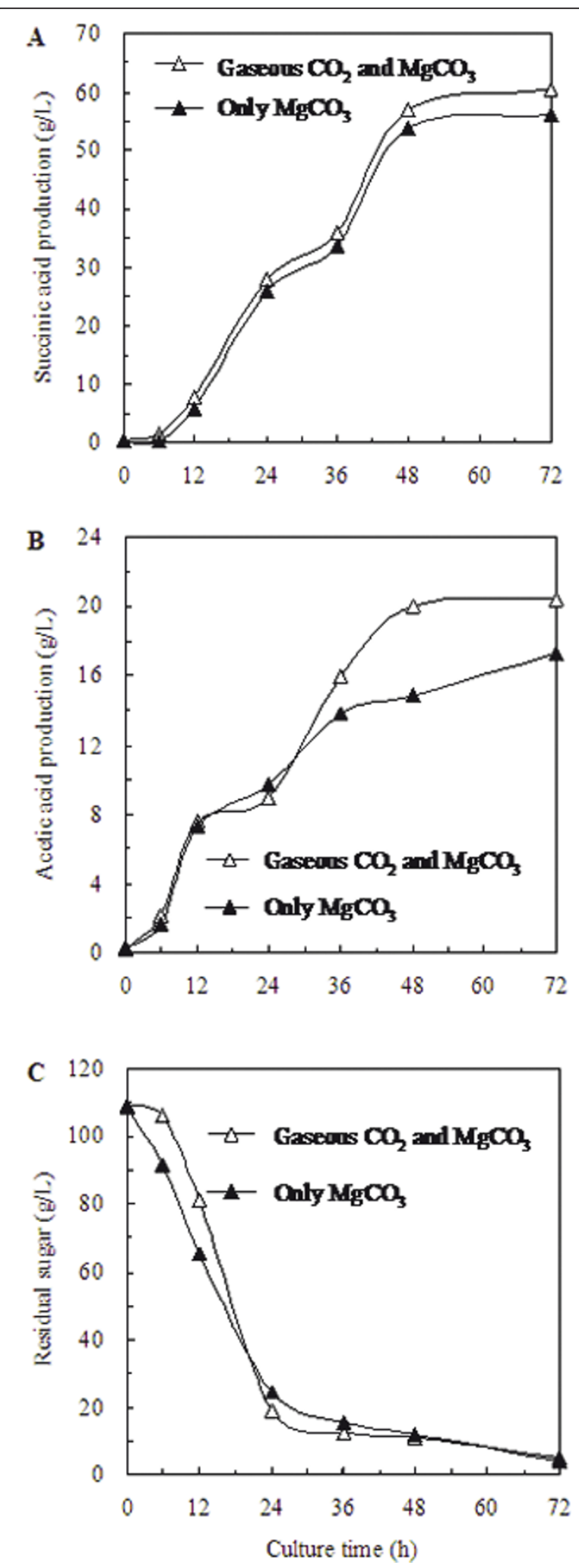

Figure 5 Effect of $\mathrm{CO}_{2}$ donor supply mode on succinic acid production during the $A$. succinogenes fermentation. (A) the succinic acid production, (B) the acetic acid production, (C) the sugar consumption. 
This is the first report investigating the replaceable of gaseous $\mathrm{CO} 2$ in the fermentation of succinic acid. The results obtained in this study may be useful for reducing the cost of succinic acid fermentation process.

\begin{abstract}
Acknowledgements
Financial support from the following funding agencies is gratefully acknowledged: the National Natural Science Foundation of China (NSFC, Project Nos. 20976038 and 21176059), the Key Project of Chinese Ministry of Education (Project No. 210132), the Hubei Provincial Natural Science Foundation for Innovative Research Team (Project No. 2008CDA002), the Scientific Research Key Project of Hubei Provincial Department of Education (Project No. Z20101401), the Discipline Leader Project of Wuhan Municipality (Project No. 200951830553), the Key Technology R\&D Program of Wuhan Municipality (Project No. 201120822280-2), the Open Project Programs for the Key Laboratory of Fermentation Engineering (Ministry of Education), the National Key Laboratory of Biochemical Engineering (Project No. 2010KF-06), and the State Key Laboratory of Bioreactor Engineering. Ya-Jie Tang also thanks the Chutian Scholar Program (Hubei Provincial Department of Education, China) (2006).
\end{abstract}

\section{Author details}

${ }^{1}$ Key Laboratory of Fermentation Engineering (Ministry of Education), Hubei University of Technology, Wuhan 430068, China. ${ }^{2}$ Laboratory of Synthetic Biology, Shanghai Advanced Research Institute, Chinese Academy of Sciences, Shanghai 201203, China. ${ }^{3}$ National Key Laboratory of Biochemical Engineering, Institute of Process Engineering, Chinese Academy of Sciences, Beijing 100080, China. ${ }^{4}$ State Key Laboratory of Bioreactor Engineering, East China University of Science and Technology, 130 Meilong Road, Shanghai 200237, China.

\section{Authors' contributions}

YJT and WZ designed the experiments, WZ carried out the experimental work, LWZ and WZ analyzed data, WZ drafted the manuscript, HML provided some critical discussions and support for this project. YJT and LWZ critically reviewed and modified the paper. All authors approved the final manuscript.

\section{Competing interests}

The authors declare that they have no competing interests.

Received: 30 June 2011 Accepted: 31 October 2011

Published: 31 October 2011

\section{References}

1. Bechthold I, Bretz K, Kabasci S, Kopitzky R, Springer A: Succinic acid: a new platform chemical for biobased polymers from renewable resources. Chem Eng Technol 2008, 31(5):647-654.

2. Song H, Lee SY: Production of succinic acid by bacterial fermentation. Enzyme Microb Technol 2006, 39:352-361.

3. Sauer M, Porro D, Mattanovich D, Branduardi P: Microbial production of organic acids: expanding the markets. Trends Biotechnol 2008, 26(2):100-108.

4. McKinlay JB, Vieille C, Zeikus JG: Prospects for a bio-based succinate industry. Appl Microbiol Biotechnol 2007, 76:727-740.

5. Zeikus JG, Jain MK, Elankovan P: Biotechnology of succinic acid production and markets for derived industrial products. Appl Microbiol Biotechnol 1999, 51:545-552.

6. Lee KY, Park JM, Kim TY, Yun H, Lee SY: The genome-scale metabolic network analysis of Zymomonas mobilis ZM4 explains physiological features and suggests ethanol and succinic acid production strategies. Microb Cell Fact 2010, 9:94

7. Yuzbashev TV, Yuzbasheva EY, Sobolevskaya TI, Laptev IA, Vybornaya TV, Larina AS, Matsui K, Fukui K, Sineoky SP: Production of succinic acid at low $\mathrm{pH}$ by a recombinant strain of the aerobic yeast Yarrowia lipolytica. Biotechnol Bioeng 2010, 107:673-682.

8. Guettler MV, Rumler D, Jain MK: Actinobacillus succinogenes sp. nov., a novel succinic-acid-producing strain from the bovine rumen. Int J Syst 1999, 49:207-216.
9. Van der Werf MJ, Guettler MV, Jain MK, Zeikus JG: Environmental and physiological factors affecting the succinate product ratio during carbohydrate fermentation by Actinobacillus sp. 130Z. Arch Microbiol 1997, 167:332-342.

10. McKinlay JB, Zeikus JG, Vieille C: Insights into Actinobacillus succinogenes fermentative metabolism in a chemically defined growth medium. Appl Environ Microbiol 2005, 71(11):6651-6656.

11. Lee PC, Lee WG, Lee SY, Chang HN: Succinic acid production with reduced by-product formation in the fermentation of Anaerobiospirillum succiniciproducens using glycerol as a carbon source. Biotechnol Bioeng 2001, 72(1):41-48.

12. Lu S, Eiteman M, Altman E: Effect of flue gas components on succinate production and $\mathrm{CO}_{2}$ fixation by metabolically engineered Escherichia coli. World J Microbiol Biotechnol 2010, 26:429-435.

13. Lee SY, Kim JM, Song H, Lee JW, Kim TY, Jang YS: From genome sequence to integrated bioprocess for succinic acid production by Mannheimia succiniciproducens. Appl Microbiol Biotechnol 2008, 79:11-22.

14. Liu YP, Zheng P, Sun ZH, Ni Y, Dong JJ, Wei P: Strategies of pH control and glucose-fed batch fermentation for production of succinic acid by Actinobacillus succinogenes CGMCC1593. J Chem Technol Biotechnol 2008, 83:722-729.

15. Song H, Lee JW, Choi S, You JK, Hong WH, Lee SY: Effects of dissolved $\mathrm{CO}_{2}$ levels on the growth of Mannheimia succiniciproducens and succinic acid production. Biotechnol Bioeng 2007, 98(6):1296-1304.

16. Lee PC, Lee WG, Kwon S, Lee SY, Chang HN: Succinic acid production by Anaerobiospirillum succiniciproducens: effects of the $\mathrm{H}_{2} / \mathrm{CO}_{2}$ supply and glucose concentration. Enzyme Microb Technol 1999, 24:549-554.

17. Rischbieter E, Schumpe A, Wunder V: Gas solubilities in aqueous solutions of organic substances. J Chem Eng Data 1996, 41:809-812.

18. Weisenberger S, Schumpe A: Estimation of gas solubilities in salt solutions at temperatures from $273 \mathrm{~K}$ to $363 \mathrm{~K}$. AlChE J 1996, 42(1):298-300

19. Mark HF, Othmer DF, Overberger CG, Seaborg GT: Kirk-Othmer encyclopedia of chemical technology New York: John Wiley\&Sons; 1981.

20. Dubois M, Gilles KA, Hamilton JK, Rebers PA, Smith F: Colorimetric method for determination of sugars and related substances. Anal Chem 1956, 28:350-356.

21. Jones RP, Greenfield PF: Effect of carbon dioxide on yeast growth and fermentation. Enzyme Microb Technol 1982, 4(4):210-223.

22. Lu S, Eiteman MA, Altman E: Effect of $\mathrm{CO}_{2}$ on succinate production in dual-phase Escherichia coli fermentations. J Biotechnol 2009, 143:213-223.

23. Samuelov NS, Lamed R, Lowe R, Zeikus JG: Influence of $\mathrm{CO}_{2}-\mathrm{HCO}_{3}{ }^{-}$levels and $\mathrm{pH}$ on growth, succinate production, and enzyme activities of Anaerobiospirillum succiniciproducens. Appl Environ Microbiol 1991, 57(10):3013-3019.

24. Badger $\mathrm{MR}$, Price $\mathrm{GD}: \mathrm{CO}_{2}$ concentrating mechanisms in cyanobacteria: molecular components, their diversity and evolution. J Eep Bot 2003, 54(383):609-622

25. Du C, Lin SKC, Koutinas A, Wang R, Dorado P, Webb C: A wheat biorefining strategy based on solid-state fermentation for fermentative production of succinic acid. Bioresour Technol 2008, 99:8310-8315.

doi:10.1186/1475-2859-10-87

Cite this article as: Zou et al: Significance of $\mathrm{CO}_{2}$ donor on the production of succinic acid by Actinobacillus succinogenes ATCC 55618. Microbial Cell Factories 2011 10:87. 